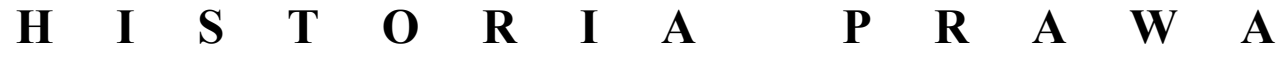 \\ KOŚCIÓŁ I PRAWO 8(21) 2019, nr 1, s. 219-230 \\ DOI: http://dx.doi.org/10.18290/kip.2019.8.1-14 \\ Artur Katolo

\begin{abstract}
ETYMOLOGY OF THE LEGAL-CANONICAL, MEDICAL AND THEOLOGICAL TERMS USED IN THE EDICT OF THE GENERAL VICAR OF THE CATANIA DIOCESE CONCERNING THE CAESAREAN SECTION AND BRIDAL BLESSING BY VINCENZO MARIA PATERNO'
\end{abstract}

\section{STATUS QUAESTIONIS}

The purpose of this article is to present the etymology of the legal-canonical, medical and theological terms appearing in the decree titled Edict of the General Vicar of the Catania Diocese Concerning the Caesarean Section and Bridal Blessing (1.06.1742) ${ }^{1}$.

Rev. ARTUR Katolo, Professor - Institute of Italian Studies at the Philological School of Higher Education in Wrocław; Higher Institutes of Religious Sciences at the Pontifical Theological Faculty of Southern Italy; ul. H. Sienkiewicza 32, 50-335 Wrocław, Poland; e-mail: someoneignotus@yahoo.com; https://orcid.org/0000-0002-2105-365X

1 Translation from old Italian into English was done by me, according to: Paternò 2001, 283-87. 


\section{TEXT OF THE EDICT AND ETYMOLOGY OF THE TERMS}

\section{[Introduction]}

"Having we carefully considered the risk of perishing without baptism[1] the childbirths[2], which remain in the womb[3] of pregnant[4] women already extinct[5]; and as we are well aware, how much more erudite writers treat the cesarean section[6], and in particular the famous Father Teofilo Rainaudo, Father Lodovico Schildere, and Father Giorgio Gobat; it is our duty to give some satisfaction with the present Edict to the serious damage that could never be achieved" [Paternò 2001, 283].

Etymology of the terms.

[1] The noun battesimo [baptism] comes from the Greek noun baptismos and means "immersion" [Bonomi 2000; Sabbadini 2001, 116; Popowski 1997, 91].

[2] The noun parto [childbirth] comes from the Latin partus, which is past participle of verb parere, parturire (in Italian partorire) [to give birth] [Bonomi 2000; Sabbadini 2001, 748; Kubicka and Suwała 2008, 116].

[3] The noun utero [womb] comes from the Latin noun uterus/utterus, which means "abdomen; stomach". Especially the Latin ut-terus is very interesting, because it is composed by particle ut [out of] and suffix -terus [further]; in the end we have the meaning of utterus as: "further, which is beyond the". The definition of the womb [uterus]: "viscera placed on the lower abdomen in females, in which the fetus is kept and grows during pregnancy" [Bonomi 2000; Kubicka and Suwała 2008, 160].

[4] The adjective pregnante [pregnant] comes from the Latin adjective praegnans. The Latin term is composed by particle prae [before] and verb agnare [make lambs] - also applied to the birth of other animals, as human being. This Latin term has been used in the traduction of the Vulgate: the Gospel of St. Luke [Bonomi 2000; Kubicka and Suwała 2008, 124].

[5] The adjective estinto [extinct; dead; deceased] comes from the Latin verb extinguere (composed by ex- and stinguere) and means "to switch off", "to burn out", "to sting", "to choke" [Bonomi 2000; Sabbadini 2001, 382].

[6] The expression parto cesareo [caesarean section] is composed by two words: parto [childbirth] and cesareo [cesarean]. About first term - see [2]. However, about cesareo it is to be said, that comes from Latin verb caedere [to cut] (past participle: caesus). Childbirth occurred through the mother's womb section [Bonomi 2000]. As it can be seen, the name "cesarean sec- 
tion" has nothing to do with the "emperor", but comes from a Latin verb caedere [to cut].

\section{[Part I]}

"And first of all, we mind to all the rectors[1] and the chaplains[2] working in our Diocese[3], to procure for all souls[4] their eternal happiness; similar, to not incurring in that divine indignation, expressed by the heavy words of Prophet Ezekiel: «Sanguinem eorum requiram de manu vestra». We order them, with the greatest concern, being called to administer the last sacraments[5] to pregnant women, they must to make the purpose of their more attention, to give baptism during the childbirth. Coming soon after the death[6] of mother, they order the cutting of the uterus; they order to the relatives, and family members, to put in the mouth a fistula of reed, which from the jaws to the lips free the channel of respiration[7] to the creature leaves; it must be supposed that child is still alive. The many experiences happened to the most zealous parish priests, one of which assures in a his letter addressed to us, having found a child alive twenty-three hours after the death of the mother" [Paternò 2001, 283-84].

Etymology of the terms.

[1] The noun parroco comes from the Greek verb parechein [to extend; to offer; to help]. Parechein is composed by para [before; at; near] and echein [to keep]. Parroco [rector] means "taking care for souls" [Bonomi 2000].

[2] The noun cappellano comes from the French noun chapelle [chapel]. Generally, a priest entrusted with the service of a chapel or oratory; the holder of a chaplaincy; a priest in charge of religious service in certain institutions [Bonomi 2000]2.

[3] The noun diocesi comes from the Greek noun dioichesis [government; administration]. This Greek term derives from dioicheo [to administer; divided living]. Whence comes the sense of "divided living in town", and then "to administer". The Greek dis means "separation" and oikeo - "to live; to dwell", as oikos - "home". "Diocese" was the ancient territorial administrative district of Asia Minor and also of the Roman Empire - the age of emperor Constantine [Bonomi 2000].

[4] The noun anima derives from the Greek noun anemos [wind; blow]. Soul is the principle of life in every organized being [Bonomi 2000].

\footnotetext{
${ }^{2}$ Cf. Cappellano, http://www.treccani.it/vocabolario/cappellano [accessed: 19.05.2019].
} 
[5] The noun sacramento comes from the Latin noun sacramentum and is composed by verb consacrare [to consecrate] and own termination of verbal names - mentum. The Latin term means "consecrated thing". In ancient times the Latins said this by oath, as the way in which a promise is made sacred. In Christianity - the sacred things instituted by Jesus Christ [Bonomi 2000].

[6] The noun morte derives from the Latin mors and means cessation of life [Bonomi 2000; Sabbadini 2001, 668].

[7] The noun respirazione comes from the Latin verb respirare [to breathe]. This verb is composed by particle re [before; ago] and spirare [to blow]. Draw the air into the lung and push it back out with the opposite motion [Bonomi 2000]. So, breathing is every single act of breathing [Sabbadini 2001, 880].

\section{[Part II]}

"We also order the same Rectors of Souls under penalty of excommunication[1] ipso incurrend for us reserved; that since in every account they must be present at the imminent death of the pregnant women, likewise, even imploring the arm of the secular justice[2], where it will be necessary; then to follow soon the cut above-mentioned: similar to washing with the waters of the baptism that creature[3] in the best form, which can be, or absolute, or conditioned: and where reasonably doubted by the rectors of the resignation of the kin of the defunct pregnant woman, at that cut; they had, in the strict duty of their office, to assist with their presence, attention and care until the end" [Paternò 2001, 284].

Etymology of the terms.

[1] The noun scomunicazione (scomunica) derives from the Latin verb excommunicare and is composed by ex- [past; former; ex] and communicare [to make participant]. Term means to exclude from the communion of the faithful [Sabbadini 2001, 958].

[2] The noun giustizia comes from the Latin noun justitia [justice]. This Latin noun derives from other noun: jus and means "right; reason". In this case, justice means the exercise of the power to judge according to the laws [Sabbadini 2001, 465; Bonomi 2000].

[3] The noun creatura derives from the Latin verb creare [to produce from the root]. The creature means everything created, especially man [Bonomi 2000]. In this case it is an unborn child. 


\section{[Part III]}

"We also order, under the same penalty, that if the experts were missing to carry out this operation, particularly in the newly-built villages, the rector is obliged to look for the best, who will be able to do. And in the case of lack, the rector can't run away to the scruples to make that cut, after having learned it from the others, in order to not perish that soul bought with the Precious Blood[1] of the Divine Lamb[2]. It is enough, as guarantee, the dictates made by Van Espen, who stated in his canonical work: «Quum non rare contingat, nullum in Parochia reperiri, aut saltem hic et nunc baberi posse, qui peritiam, modumque convenientem aperiendi uterum, et extrahendi infantem habeat; portet, ut ipsìmes Pastores, precipue rurales, huius rei aliquam notitiam a Perito aliquo accipiant, qua subinde, cogente necessitate uti possint»” [Paternò 2001, 284-85].

Etymology of the terms.

[1] The noun sangue comes from the Latin noun sanguis [thin blood, flowing in the veins; principle of the life]. Sanguis is something different from the other Latin term cruor, which means "thick blood, clotted, gushed from the wound" [Bonomi 2000].

[2] The phrase Agnello Divino is composed by the two words (noun and adjective) and in the theological terms means Jesus Christ - his chaste and meek figure. The noun agnello is a diminutive form of the Latin agnus [lamb] - diminutive agnellus. This Latin term corresponds to the Greek noun amnos/agnos. Some explain, that agnos, composed by $a$ - [not; no] and gonos [bearing; to generate], means "has not yet generated". Others say, that agnos means "pure, chaste, without vice". Instead the noun amnos, composed by $a$ - [not; no] and menos [anger], means "without anger, meek". But these significant are more sentimental than real. In reality, the Latin agnus means "goat, male of the sheep" [Bonomi 2000; Sabbadini 2001, 30; Popowski 1997, 28; Kubicka and Suwała 2008, 22].

The adjective divino is form derived from the Latin divus [shining, heavenly]. The term indicates something that belongs to God, which proceeds from God [Sabbadini 2001, 335; Bonomi 2000; Kubicka and Suwała 2008, 57].

\section{[Part IV]}

"If ever happened, that the relatives of the extinct pregnancy under some vain pretext were opposed to this incision, or the cerulics[1] demanded a wage for something else not due to them for justice, to which the 
forces of those relatives could not; then the rectors must first use all the pleasant means to come to the cesarean birth; and if otherwise, to give to both the penalty of excommunication ipso facto incurrenda, and to all those still, that impedere to put in instinct of eternal health[2] those souls enclosed in utero. Although in cases of occult pregnancies[3], and infamous[4], the rectors must proceed with those concerns which will be dictated by prudence[5] and morality" [Paternò 2001, 285].

Etymology of the terms.

[1] The noun cerusico derives from the Latin chirurgus [surgeon]. This Latin term comes from the Greek cheir-urgos and means someoen, who treats diseases with the use of a hand bare or armed with instruments. In fact, cheir means "hand" and urgos (ergon) - "work" [Bonomi 2000; Sabbadini 2001, 192; Kubicka and Suwała 2008, 38]. In the New Testament (cf. Mk 2,17; 5,26; Lc 4,23; 5,31; 8,43; Col 21,16-17) the surgeon is called iatros - "physician, surgeon" [Popowski 1997, 287].

[2] The expression eterna salute. The noun salute comes from the Latin salus [integrity, safety, salvation]. The adjective eterna derives from the Latin aeternus, which is composed by the noun aevum [age, duration, infinite] and the suffix ternus. Areternus means "which lasts forever; which has no beginning, neither half, nor the end". Then, the expression eterna salute [eternal health] means "perfect state of well-being (of happiness) forever (without limits)" [Bonomi 2000; Sabbadini 2001, 384, 929].

[3] The expression gravidanza occulta. The noun gravidanza derives from the Latin garvidus, which is composed by gravis [who has weight] and the ending - idus [to indicate: "the lasting quality"]. Then gravidanza [pregnancy] means "carrying the baby in the womb" [Bonomi 2000; Sabbadini 2001,475$]$.

The adjective occulto derives from the Latin verb occulere [to hide from the eyes of others with a veil, to hide]. This term is composed by $o b$ [before, against] and coulere [to grow, to breed] [Bonomi 2000]. Then, etymologically, the expression gravidanza occulta [occult pregnancy] means "a woman carrying a child in the womb in secret".

[4] The noun infame comes from the Latin infamem, composed by in [not, no] and fama [fame, voice]. Then infame [infamous] means "bad face; shameful; spotted gravely and notoriously in honor" [Bonomi 2000; Sabbadini 2001, 529]. 
[5] The noun prudenza comes from the Latin verb providere [to see first; to foresee]. This verb is composed by pro [before] and videre [to see]. Then prudenza (the Latin noun prudentia) means "caution, prudence"; the Latin verb providere means "to procure before what you need; to have the eye on anything and watch over it" [Bonomi 2000; Sabbadini 2001, 837].

\section{[Part V]}

"Since dictates of more learned and serious writers, probably even in practice, that the mother is often praised, by the precept of charity[1], to suffer some new pain[2] from the cut: for her it will be a price of her eternal happiness. However, rectors will do the most of their duty teaching such doctrine, where they will explain, that the caesarean section will be good. Since now, after so many trials, the surgical art, with the certain instruments[3], can keep alive the pregnant woman, and the same time to let the creature to get out from the womb, and to baptize it" [Paternò 2001, 285].

Etymology of the terms.

[1] The expression precetto della carità. The noun precetto derives from the Latin verb praecipere [to take, to occupy first; to forecast; to predispose; to command; to teach]. This Latin verb is composed by prae [forward] and cipere [to take; to occupy]. The term precetto [precept] means: "what is recommended as a rule and teaching; command; prescription; order" [Bonomi 2000; Sabbadini 2001, 804].

The noun carità derives from the Latin caritas [good will; love] and corresponds to the Greek charis. This term means "selfless love for God and neighbor; compassion" [Bonomi 2000; Sabbadini 2001, 170].

[2] The noun dolore comes from the Latin dolor [pain]. This Latin term derives from the verb doleo and means "I feel bad; I regret" [Bonomi 2000; Sabbadini 2001, 339].

[3] The noun strumento derives from the Latin noun insrumentum, which comes from the verb instruere [to build; to lay; to arrange; to place]. This term means "everything with which and by which one operates; tool; device; machine" [Bonomi 2000; Sabbadini 2001, 1065; Kubicka and Suwała 2008, 87].

\section{[Part VI]}

"To the extent of such an important affair the rectors will use all the attention and care, to see, if the mother is died. Before coming to the cut, they must make sure, if she is really expired, using: the light of a wax candle approached to the lips[1], or the glass jar filled with water placed 
on the navel[2] of pregnant; thanks to the movement of which, they will be able to make sure, if she is still alive or not. So make sure, that she already expired, all the most exquisite shrewdness will be used, not only to carry out the birth, but to examine, whether it is more than one child, in order to administer them the baptism" [Paternò 2001, 286].

Etymology of terms.

[1] The noun labbro (in text is used labro) derives from the Greek verb laptein [to lick]. This Greek term corresponds to the Latin lambere [to lick]; and respectively the Latin noun labium/labrum. Some say, that labbro [lip] comes from the Greek verb labo [I take] [Bonomi 2000; Kubicka and Suwała 2008, 92; Sabbadini 2001, 576]. In the New Testament is used term stoma [lip]: es. Mt 15,11; Lc 1,64.70; Rom 3,14 [Popowski 1997, 565].

[2] The noun orifizio (in text is used orificio) comes from the Latin noun orificium [navel] and is composed by os [mouth] and ficere/facere [to do]. Then navel [orificio] is "more or less narrow opening, which leads to a cavity in the animal body" [Bonomi 2000; Sabbadini 2001, 721].

\section{[Part VII]}

"And here deserves a special remembrance of the very strict debt, which the rectors[1] yearned not to wait but to prevent with their zeal the invitations of the dangerous infirmaries of their parish[2], to be always ready to help them, to rise them, in the right way of the true lovers of the souls: hearing their confessions[3], administering them viaticum[4] and extreme unction[5], deigning them with a constant and servant assistance in the last periods of their life, and maxims, where there are poor and in need of the help" [Paternò 2001, 286].

Etymology of the terms.

[1] The noun piovano/pievano derives from the Latin plebanus, which comes from the plebs [plebeians; people]. This term indicates "priest, who has the spiritual government of a people living in the perimeter of his parish" [Bonomi 2000; Sabbadini 2001, 780; Kubicka and Suwała 2008, 121$22]$.

[2] The noun pieve derives from the Latin plebem [plebeians; people] and means "country population, centered on a church". Then parish, which has several rural villages below it [Bonomi 2000; Sabbadini 2001, 780].

[3] The noun confessione derives from the Latin verb confiteri [to confess]. This verb is composed by cum [with] and fateri [to declare spontaneously]. The term means "to say a real thing; to manifest; to declare 
openly". Then confession is "declared recognition of a fault or wrong" [Sabbadini 2001, 242; Bonomi 2000; Kubicka and Suwała 2008, 44].

[4] The noun viatico derives from the Latin viaticum [provision for travel], which comes from the noun via [street; walk], as well as from the verb viare [to make way]. In the Christian world it means the Sacrament of the Eucharist administered to the dying, in order to arrange them for the great journey of eternity [Bonomi 2000; Sabbadini 2001, 1164].

[5] The expression estrema unzione. The adjective estremo derives from the Latin extremus, which is superlative of the adjective exter/exterus. Exter/exterus comes from ex [which is more out of all; out]. In this case estremo is a deadline in space or time; the most serious; the last step [Bonomi 2000; Sabbadini 2001, 383].

The noun unzione derives from the Latin verb ungere/unguere [to anoint; to grease; to spread oil or some fat]. Then, extreme unction [estrema unzione] means "to anoint with the holy oil of the dying". Today the term "sacrament of the sick" is used [Sabbadini 2001, 1142; Bonomi 2000].

\section{[Part VIII]}

"The Holy Church puts the bridal blessing[1] in great consideration. It is fitting for us to excite the zeal of the rectors, so that they do not cease to exonerate the spouses[2] with great care, to come to the church, to attend Mass[2] pro Sponso et Sponsa, and to receive the blessing, and to not put that in trouble, as relatives, who should be exemplary for others, depriving themselves a lot. To overcome the reluctance to dictate our faith in such a different way, let the rectors strive to make them understand, how great is the fruit of this blessing forever, from which the admiration can be found; and this blessing is a rare and happy success for them. But it is necessary to warn them, that they are not worthy of this blessing, and for this reason, let them come to the church, to deserve to receive this blessing with great respect, so that they will be united in the marriage bond[3]." [Paternò 2001, 286].

Etymology of the terms.

[1] The expression benedizione nuziale. The noun benedizione comes from the Latin verb benedicere [good to say]. Blessing means to invoke good from God in favor for thing or person [Bonomi 2000; Sabbadini 2001, 120].

The adjective nuziale derives from the Latin noun nuptiae [wedding; the act of contracting marriage]. Then, bridal blessing [benedizione nuziale] means to invoke good from God during the contracting marriage [Bonomi 2000; Sabbadini 2001, 694, 700]. 
[2] The noun messa derives from the Latin noun missa, which in Roman civilization meant the dismissal formula of the superior to the inferiors; this Latin noun comes from the verb mittere [to send]. In ecclesiastical language, missa means the sacrifice of the Body and Blood of Jesus Christ, according to the prescribed rite [Bonomi 2000; Sabbadini 2001, 646].

[3] The expression vincolo del matrimonio. The noun vincolo [bond] derives from the Latin verb vincire [to tie; to wrap; to gird]. Then bond [vincolo] means the imposition, constraint, legal, moral or social obligation [Sabbadini 2001, 1167; Bonomi 2000].

The noun matrimonio comes from the Latin noun matrimonium [marriage]. This Latin noun is composed by mater [mother; genetrice] and the suffix - monium. The marriage bond [vincolo del matrimonio] is the legitimate union of man and woman with the purpose of generating children [Sabbadini 2001, 636; Bonomi 2000].

\section{[Part IX]}

"The rectors, therefore, will instruct the fiances[1], so that they stay far away from the abuse so pernicious to their souls. Let the rectors converse familiarly with each other, with due caution, without the living presence of their closest relatives, first, that they ratify their marriage in faciem Ecclesiae. They warn him clearly, however, about the near danger of sinning[2], if they go to dwell together in the same house at night. They will make them aware, by now, of being incurred in the excommunication ipso facto reserved to us and delegated to the vicars, rectors and chaplains of our diocese, according to Costantino Roncaglia, eminent theologian from the Congregation of Mother of God, in his moral work De Sponsalibus, in Chapter III, in Rule VIII on the question before. This punishment[3] was previously proposed and ordered by the zealous and wise prelate[4] of the Diocese of Lucca, with these precise words: Sponsi de futuro sub eodem tecto pernoctantes sine nostra, vel Vicarii Generalis licentia, incidunt ipso facto in excomunicationem nobis reservatam. Our present ordination and punishment we declare as binding. This document will have to to be explained to the people several times a year, that he will keep them alive in memory and practice according to his own conscience[5]. And we order, that the present Edict[6] will be placed and kept in the sacristies[7] of the churches of our diocese. Vincenzo Maria Paternò, Trigona, General Vicar. Catania, 1st June 1742" [Paternò 2001, 287]. 
Etymology of the terms.

[1] The expression novelli sposi (used in the text) must be considered as fidanzati/promessi sposi. The noun fidanza derives from the Latin verb $f i$ dere [to have faith]. The term means "to promise solemnly to marry; promise of marriage" [Bonomi 2000; Sabbadini 2001, 409].

[2] The verb peccare derives from the Latin verb peccare [to make mistakes; to fail; to miss]. The origin of the Latin verb is unknown [Bonomi 2000; Sabbadini 2001, 756].

[3] The noun censura (used in the text) derives from the Latin verb censere [to rate; to determine; to decide]. In the ancient Rome the censor's office, which had the right to examine the conduct of the citizens to impose blame on those of unregulated habits. In ecclesiastical language - a sort of ecclesiastical penalty imposed by canons, or by the pope, to those who do not obey the laws of the Church [Bonomi 2000; Sabbadini 2001, 183-84].

[4] The noun prelato derives from the Latin verb (praefero) in participle passive praelatus [favorite; responsible]. This Latin term is composed by prae [before] and latus [brought]. It is a title proper to the principal ecclesiastical superiors [Bonomi 2000; Sabbadini 2001, 813].

[5] The noun coscienza derives from the Latin verb conscire [to be aware]. This verb is composed by the particle con/cum [with; by; to] and the verb scire [to know]. The term means the awareness of what is happening in us [Sabbadini 2001, 272; Bonomi 2000].

[6] The noun editto comes from the Latin verb edictere [to speak]. It is composed by $e$ [out] and the verb dicere [to say]. Then, the edict [editto] means "the ordinanze pronounced by those with the highest authority" [Bonomi 2000; Sabbadini 2001, 352].

[7] The noun sacristia derives from the barbarian Latin sacristia [sacristia]. It means "place where the sacred furnishings are" [Bonomi 2000; Sabbadini 2001, 926].

\section{LITERATURE}

Bonomi, Francesco. 2000. Vocabolario Etimologico della Lingua Italiana. www.eti mo.it [accessed: 4.05.2019].

“Cappellano." http://www.treccani.it/vocabolario/cappellano [accessed: 19.05.2019].

Cinti, Decio. 2001. Nuovo Dizionario dei Sinonimi e dei Contrari. Novara: De Agostini.

Kubicka, Emilia, and Monika Suwała, ed. 2008. Stownik łacińsko-polski, polskotaciński. Toruń: Buchmann. 
Paternò, Vincenzo Maria. 2001. "Editto del Vicario Generale della Diocesi di Catania Intorno al Parto Cesareo, e Benedizione Nuziale (1 giugno 1742).” In Francesco Emanuello Cangiamila, Embriologia Sacra, 283-87. Roma: CIC.

Popowski, Remigiusz. 1997. Wielki Stownik Grecko-Polski Nowego Testamentu. Warszawa: Vocatio.

Sabbadini, Sergio, ed. 2001. Dizionario della lingua italiana. Novara: De Agostini.

Etymology of the Legal-Canonical, Medical

and Theological Terms Used in the

Edict of the General Vicar of the Catania Diocese Concerning

the Caesarean Section and Bridal Blessing by Vincenzo Maria Paterno'

Su m m a r y

The purpose of this article is to present the etymology of the canonical, legal, medical and theological terms used in the 1742 decree of the Vicar General Editto del Vicario Generale della Diocesi di Catania Intorno al Parto Cesareo, e Benedizione Nuziale. The edict was written in the Italian language of the 18th century. The text was translated into English using the original spelling of the document.

Key words: linguistics; source text; particular law; Sicily

\section{Etymologia terminów kanoniczno-prawniczych, medycznych i teologicznych w Edict of the General Vicar of the Catania Diocese Concerning the Caesarean Section and Bridal Blessing autorstwa Vincenzo Maria Paterno'}

Streszczenie

Celem niniejszego artykułu jest przedstawienie etymologii terminów kanonicznoprawniczych, medycznych i teologicznych występujących w dekrecie Wikariusza Generalnego z 1742 r., zatytułowanego Editto del Vicario Generale della Diocesi di Catania Intorno al Parto Cesareo, e Benedizione Nuziale. Wyżej wspomniany edykt został napisany w XVIII-wiecznym języku włoskim. Tłumaczenia na język angielski dokonano na podstawie oryginalnej pisowni dokumentu.

Słowa kluczowe: językoznawstwo; tekst źródłowy; prawo partykularne; Sycylia

Informacje o Autorze: KS. PROF. DR HAB. ARTUR KATOLO - Instytut Italianistyki Wyższej Szkoły Filologicznej we Wrocławiu; Wyższy Instytut Nauk Religijnych Papieskiego Wydziału Teologicznego Południowych Włoch; adres do korespondencji: ul. H. Sienkiewicza 32, 50-335 Wrocław, Polska; e-mail: someoneignotus@yahoo.com; https://orcid.org/0000-0002-2105-365X 